\title{
Household Income Investigation in Smallholder Cattle Farming At Minahasa Regency North Sulawesi Province-Indonesia
}

\author{
"E. Wantasen, U Paputungan \\ Faculty of Animal Science, Sam Ratulangi University, Indonesia \\ Corresponding Author: E. Wantasen
}

\begin{abstract}
The study was performed out in Tumaratas Village, Minahasa Regency Indonesia.The aim of this research was to know the income obtained in smallholder cattle farmer's household, examine earning share of cattle farming to the total household income and factors affecting household income from cattle farming business as well. Data collection were conducted through 100 farm households which were selected as respondents using stratified purposive sampling method. Respondents were grouped into three strata based on the number of cattle ownership. Stratum 1 raised 1- $\leq 5$ AUs consisted of 93 respondents, stratum 2 owned 5-10 AUs consisted of 5 respondents and stratum 3 managed $>10$ AUs consisted of 2 respondents. Data were analyzed by using descriptive and quantitative analysis. The study indicated that more than $50 \%$ of household's income derived from cattle farming. Earnings from cattle business in stratum 2 and 3 showed a higher (>60\%) contribution to household's income compare to stratum 1 (50\%). The returns from cattle farming tend to increase with an increase on herd size. Besides, Households in stratum 1 get more income from crops (i.e. onion, maize, tomato, red bean, peanut) due to a few cattle they had raised. Partially, the variables that could significantly effected farmers' income from cattle business were number of cattle, family labor, inseminator cost, cost of natural mating, value added of cattle and land size whereas education of head had significantly not influenced farmers income.
\end{abstract}

Keywords: Cattle farming, Household's income, crops, income share.

\section{Introduction}

More than $90 \%$ of beef cattle production in Indonesia is derived from smallholder cattle operations, often with only 2-3 cattle per household. Many farmers in North Sulawesi Province Indonesia keep cattle for draught power, fattening, manure, and as a form of savings to be sold when cash is needed. The cattle which is raised by the farmers derived from ongole crossbreed cattle since it considered providing much benefit for large number of farmers. Minahasa Regency is an important region for dual purpose cattle business development in North Sulawesi Province Indonesia. The region supplies $25 \%$ of the total cattle numbers in North Sulawesi Province. Besides cattle farming has immense potential to employ peoples who worked in agriculture sector in rural area [ 1,2,3]. Agriculture sector in Minahasa Regency is mostly constitute a subsistence farming system, whereby mostly of rural population gets income from crops, fisheries and livestock [4]. Households in villages located in Minahasa Regency are traditionally managing cattle in small scale business, and, the cattle remains utilized as a source of farm labor processing and transportation of agricultural products. Peoples in rural area are also involved in non farm activities such as trading, national civil servant, non agriculture worker. However low level of education and skill cause non farm income are still limited

The development of beef cattle farming in Indonesia has shown a positive effect in rural development $[5,6]$. Beef cattle farming can support cash income and employment in rural communities and can also assist in empowering farmers' income [7,8,9] Besides cattle business can absorb under utilized labor therefore it has potential to decrease migration rate from rural to urban and then it will decrease the rate of urbanization. Household labor participation in rearing cattle has become important because it provides supplementary household income, improves member of household nutrition and decreases household dependency on local money lender [10]. Several study showed the positive effect of input factor on beef cattle production, production cost, revenue and income as well as in dairy farm $[11,12,13]$. Unfortunately evaluation of income assessments of dual purpose type of cattle in developing country like Indonesia is still limited. Therefore this study examines the income of dual purpose cattle business in Minahasa Regency and their affect on household sustainability and factors influencing household income. The results of this study are expected of importance to the government in designing rural development strategies in Minahasa Regency North Sulawesi Province. Thus the objectives of this research was to know the income obtained in smallholder cattle farmer's household and 
examine both earning share of cattle farming to the total household income and factors effecting Household income from cattle business in Minahasa Regency.

\section{Methodology}

\subsection{Theoritical Framework}

Cattle farm households allocate time to three daily activities: (a) in the labour market (b) in home activities and (c) leisure time. In this study, work activities comprise all productive activities, on- and non- dairy farming yielding income in cash or in kind. The relationship of time constraint can be stated as Gronau' s model:

$T=\sum_{i=1}^{n} T s i=T w i+T h i+T l i$

Where :

$\mathrm{T}$ : total time available to the ith dairy farmer household,

Twi : time allocated to market work in the $\mathrm{i}^{\text {th }}$ household,

Thi : time allocated to home production in the $\mathrm{i}^{\text {th }}$ household and

T1i : time allocated to leisure in the $i^{\text {th }}$ household.

The work activities include time-use by all household members: male and female in income-generating activities. The household's time spent on three separate activities can be viewed as [14]:

$T i=\sum_{1}^{n} T i=\sum_{i=1}^{n} \sum_{j=1}^{3} \sum_{k=1}^{2} T i j k$

Where :

Twi $=$ Total time allocated to market work

$i \quad i^{\text {th }}$ member of household

$\mathrm{j}=\mathrm{j}^{\text {th }}$ activities $(1=$ market work, $2=$ household activity, $3=$ leisure time $)$

Households consumption is fulfilled by households income to miximize their utility. Since decisions of labor allocation in household were made, income has become indogenous factor. Marginal utility of family income is decreased by the higher level of household revenues, ceteris paribus. Therefore this situation will diminish households' labor allocation to work relative to spent the time in leisure. Household income is function of time spent by all of family members to work both in work activities (i.e. cattle farm, off farm , non farm) and from non work income. The income of cattle farming can influence decision-making in allocating household labour time to cattle farming activities. Theoretically, higher earning can attract household labour to allocate more time to those activities. Therefore, income from cattle farming can determine whether household labour should be devoted more, or less, to cattle farming activities. Non-labour income, such as remittances, rent and interest, may decrease the time allocated to work activities, including cattle farming. Household labour tends to be lessen the time in work for pay and increase leisure because of the accruing non labour income. The household labour spent their time in cattle farming activities may influence by non-work activities. The income constraint would be formulated as:

$$
\begin{aligned}
Y & =\sum_{i=1}^{n} Y i \\
& =\sum_{i=1}^{n} \sum_{j=1}^{m} W_{i j} T_{i j}+\sum_{i=1}^{n} V_{i}
\end{aligned}
$$

Where :

$\mathrm{i}^{\text {th }}=$ Individual

$\mathrm{j}^{\text {th }}=$ activity $(1=$ cattle farm, $2=$ farm and non farm $)$

$\mathrm{W}_{\mathrm{j}}=$ wage rate for $\mathrm{j}^{\text {th }}$ activity 
$\mathrm{T}_{\mathrm{j}}=$ time unit allocated by $\mathrm{i}^{\text {th }}$ individual in $\mathrm{j}^{\text {th }}$ activity

$\mathrm{V}_{\mathrm{j}}=$ non wage income generated by $\mathrm{i}^{\text {th }}$ individual

If income is a constraint in utility maximisation, the expenditure on market goods cannot exceed the family income. It can be couched:

$\mathrm{V}_{\mathrm{i}}+\sum W_{i} T_{w i}=\sum P_{i} \mathrm{Q}_{\mathrm{mi}}$

$\mathrm{Tw}=\mathrm{Ts}-\mathrm{Th}-\mathrm{Ti}$

$\mathrm{Vi}+\sum W i(\mathrm{Ts}-\mathrm{Th}-\mathrm{Ti})=\sum P i \cdot \mathrm{Qmi}$

$\mathrm{Vi}+\sum W i . \mathrm{Tw}=\sum P i . \mathrm{Qmi}+\sum W i . \mathrm{Th}+\sum W i . \mathrm{Tl}$

where:

$\mathrm{Wi}=$ wage rate for $\mathrm{i}^{\text {th }}$ activity,

Ts $=$ Total time unit available on $\mathrm{i}^{\text {th }}$ cattle farmers household

Th $=$ time allocated to home production in the $\mathrm{i}^{\text {th }}$ household

$\mathrm{Tw}=$ time units allocated by $\mathrm{i}^{\text {th }}$ activity,

$\mathrm{Pi}=$ the price for $\mathrm{i}^{\text {th }}$ market goods, and

Qmi = the consumption for ith market goods.

\subsection{Research Methode}

The study was conducted in Tumaratas village West Langowan district Regency of Minahasa North Sulawesi Province. Tumaratas village was purposively chosen based on a greater number of dual purpose cattles in Minahasa Regency and a large number of catte farmers involved in this area compared to other regions. One hundreds households as sample respondents selected by stratified purposive random sampling considering land holdings and at least had one cattle and ever sold it out. The formulation of formative sample size calculated by [15] as follows:

$$
n=\frac{N}{N(d)^{2}+1}
$$

Where :

$\mathrm{n}=$ Number of sample

$\mathrm{N}=$ Number of population

$\mathrm{d}=$ Sample error (critical value 5\%)

Sample was devided into three stratum of cattle ownership consist of stratum 1 (raised 1- $\leq 5$ Animal Units (AUs); $n=93$ ), stratum 2 (managed 5-10 AUs, $n=7$ ), and stratum 3 ( owned $>10$ AUs; $n=2$ ). Data were collected by using survey method with interview directly to farmers assisted by questionnaires taken in February- April 2017. Household members aged 15-64 years old were interviewed separately to obtain required data. In order to get reliable data related to the households labor allocation, respondents were asked to provide information about various activities undertaken to meet households' income. The household labor activities were scheduled through four strategy : by time activities of day, by day of week, by a day of a month and by a day of a year to guide respondents recollecting their involvement in the past 12 months. Cobb-Douglass model of production function was used to analyze factors influencing farmers' income from cattle farming [16] :

$\operatorname{Ln} Y=\alpha 0+\alpha 1 \operatorname{Ln} X 1+\alpha 2 \operatorname{Ln} X 2+\alpha 3 \operatorname{Ln} X 3+\alpha 4 \operatorname{Ln} X 4+\alpha 5 \operatorname{Ln} X 5+e$

Where :

$\mathrm{Y}=$ Income from cattle business (IDR/year)

$\mathrm{X} 1=$ Number of cattle $(\mathrm{AUs} /$ Household $)$

$\mathrm{X} 2=$ Family labor on cattle business (Man days/year/household)

$\mathrm{X} 3=$ Value added of cattle $($ IDR/year/household $)$

$\mathrm{X} 4=$ Land size $($ Hectare/household $)$

$\mathrm{X} 5=$ Farmers education $($ Year $)$

$\mathrm{X} 6$ = Inseminator cost (IDR/year/household)

$\mathrm{X} 7$ = Cost of natural mating ( IDR/year/household)

$\alpha 0=$ Constant

$\alpha 1, \ldots \ldots . \alpha 7=$ Regression coefficient of each variable X1,..X7 (Independent variables)

e $\quad=$ error term 
Descriptive and quantitative analysis was conducted using SAS package for analyzing data.

\section{Household Income}

\section{Results And Discussion}

Household income of dual purpose cattle farmers in Tumaratas Village were classified into cattle farming and non cattle farming sources including of on farm and non farm activities. More than $50 \%$ of household income was contributed by dual purpose cattle farming activities. The income from cattle farming tend to increase with an increase on herd size. Besides, Households in stratum 1 get more income from on farm $(24.45 \%)$ (i.e. onion, maize, tomato, red bean , peanut) due to a few cattle they had raised (Table 1)

Table 1. Annual Household Income by Stratum per Animal Unit of Cattle farming In Tumaratas Village

\begin{tabular}{lrrrr}
\hline \multirow{2}{*}{ Income source } & \multicolumn{4}{c}{ Total household income (IDR/Animal unit/year) } \\
\cline { 2 - 5 } I.Work income & \multicolumn{1}{c}{$\mathbf{1 -} \square$ 5 AUs } & \multicolumn{1}{c}{ 5-10 AUs } & \multicolumn{1}{c}{ Total sample } \\
Cattle farming & $11,020,622(50.88 \%)$ & $14,171,842$ & $15,012,617$ & $11,555,751(53.98 \%)$ \\
Outside cattle farming & & $(65.57)$ & $(69.11 \%)$ & \\
a. On farm & $5,294,059(24.45 \%)$ & $3,397,059(15.71 \%)$ & $3,252,387(14.97 \%)$ & $4,980,043(23.26 \%)$ \\
b. Off farm & $1,611,246(7.43 \%)$ & $535,632(2.47 \%)$ & $2,083,333(9.59 \%)$ & $1,492,198(6.97)$ \\
c. Non farm & $2,931,878(13.53 \%)$ & $3,267,816(15.12 \%)$ & $1,000,000(4.60 \%)$ & $2,905,784(13.57 \%)$ \\
Total work income & $20,857,805$ & $21,372,349$ & $21,348,337$ & $20,933,776$ \\
II.Non work income & $798,766(3.68 \%)$ & $238,544(1.10 \%)$ & $374,448(1.72 \%)$ & $470,586(3.49 \%)$ \\
Total household & $21,656,571(100 \%)$ & $21,610,893(100 \%)$ & $21,722,785(100 \%)$ & $21,404,362(100 \%)$ \\
income & & & & \\
\hline
\end{tabular}

The income from cattle business was the difference between the revenues received by household with all of its production cost. Cattle revenues in this study was derived from the sale of cattle, renting of males, renting cattle labor, the value production of manure and the value of cattle that have not been sold while the cost of cattle production was feed cost, health costs, cage costs, labor costs, inseminator and the cost of natural mating. The cost of purchasing cattle is not included in the income calculation because of limited information from farmers about the purchase price of cattle. Farmers know the selling price because they sold cattle however farmers didn't know the purchase price of cattle because they never bought cattle unless it was obtained by inheritance of parents, artificial insemination process or natural mating. Income from food crop farming was the difference of the revenues earned by farmers from food crop farming such as corn, rice, peanut, red bean, onion, tomato and leek with production cost for one year. Income from off farm activity was the difference of revenues and production cost from farm workers, processing and selling agricultural products for a year. Revenue from outside agriculture was the difference between households' income outside the agricultural sector such as non-agricultural workers, income from public service, private employees, small shop business, money lender services, construction workers. Whereas non work income was derived from remittances and contribution of children to parents.

Table 1 indicated that The entire strata of livestock ownership constitute semi-commercial farming because of its contribution between 30-70 percent of household income [17]. The income per animal unit of the dual purpose cattle business was relatively higher due to the high price. The high value of cattle because the cattle was useful as a source of labor in land farming, as a tillage and beneficial to carried away production inputs and farm products. Other reasons were cows that have an attractive appearance such as white, high hump, and have a special sign on his body such as there was a round-shaped mark on the head or back of cattle. Cattles generated from insemination process usually have a higher price than cows born from natural mating. A pregnant female cattle had a sale value that was almost twice the price of a normal value. Although the price of cattle in the research area was relatively high but farmers will not sell their cows at all times. Farmers will only sell their cows if they require additional costs such as to pay for children's schooling, house building, cost of family health, or other things that require large number of expense, so farmers consider cattle was a savings that could be sold when needed.

\section{Dual Purpose Cattle Income}

Farmer's income from dual purpose cattle business was getting bigger with increasing of ownership. Table 2 showed that the income from cattle is mostly derived from the sale of cattle followed by the results of rent out cattle labor, hired out the bulls and sold manure. 
Table 2. Income From Cattle Farming by Stratum at Tumaratas Village, Minahasa Regency

\begin{tabular}{llrr}
\hline \multicolumn{2}{c}{ Variables } & \multicolumn{2}{c}{ Annual Household Income from Cattle Business (IDR/year) } \\
\cline { 2 - 4 } I. Revenues & $13,67632,736$ & $\mathbf{5 - 2 0}$ AUs & $>\mathbf{1 0}$ AUs \\
\cline { 2 - 4 } & $8,321,516$ & $15,534,015$ & $16,093,670$ \\
a. Rent out cattle labor & $3,465,970$ & $9,525,700$ & $10,353,240$ \\
b. Rent out out stud & & $3,972,865$ & $3,516,280$ \\
$\quad$ cattle & $1,875,250$ & \\
c. Sold manure & $2,803,679$ & $2,035,450$ & $2,224,150$ \\
II. Total cost & $2,450,376$ & $1,554,878$ & $1,183,217$ \\
a. Variable cost & 353,303 & $1,219,512$ & 962,500 \\
b. Fixed cost & $11,020,622$ & 335,366 & 220,712 \\
III. Income & & $14,171,842$ & $15,012,617$ \\
\hline
\end{tabular}

The most interesting finding in this study was that households earn income from selling cattle and rent out cattle labor both to cultivate farmland and transportation also to be stud cattle. Breeders in the area of study were still doing a natural mating system for their livestock due to limited inseminator officer. However, cattle produced from insemination have higher selling price than cows produced through natural marriage system because of the physical shape and health of livestock considered better by farmers. Meanwhile, the number of good stud is limited so that the rent price of stud cattle was quite expensive. The average cost of renting a stud bull was IDR 350,000- 400,000 for a single marriage process. However, cattle produced from insemination have higher selling price than cows produced through natural marriage system because of the physical shape and and health of livestock considered better by farmers. The average selling price of a young cattle ranges from IDR.3 million - 6 million per head while an adult price between IDR 7,000,000 to 11,500,000 per head depending on the physical condition of the cattle. Revenue from manure was still relatively low due to the limited knowledge by farmers in processing manure into organic fertilizer and also because farmers in this region have not been accustomed to use organic fertilizer. The income from livestock was used to buy farming inputs, to pay for education of their children , children' wedding or to pay for household' member which had been ill and have to get treatment in hospital. The average variable cost accounted for $78.43 \%$ of all production costs and forage costs covering $74, .82 \%$ of expenditure. While fixed costs included $21.56 \%$ including depreciation expenses. Forage in the study area was not traded so the calculation used the labor cost approach to feed the cattle. Forage cost per animal unit tend to decrease as the herd size increased (Fig. 1)

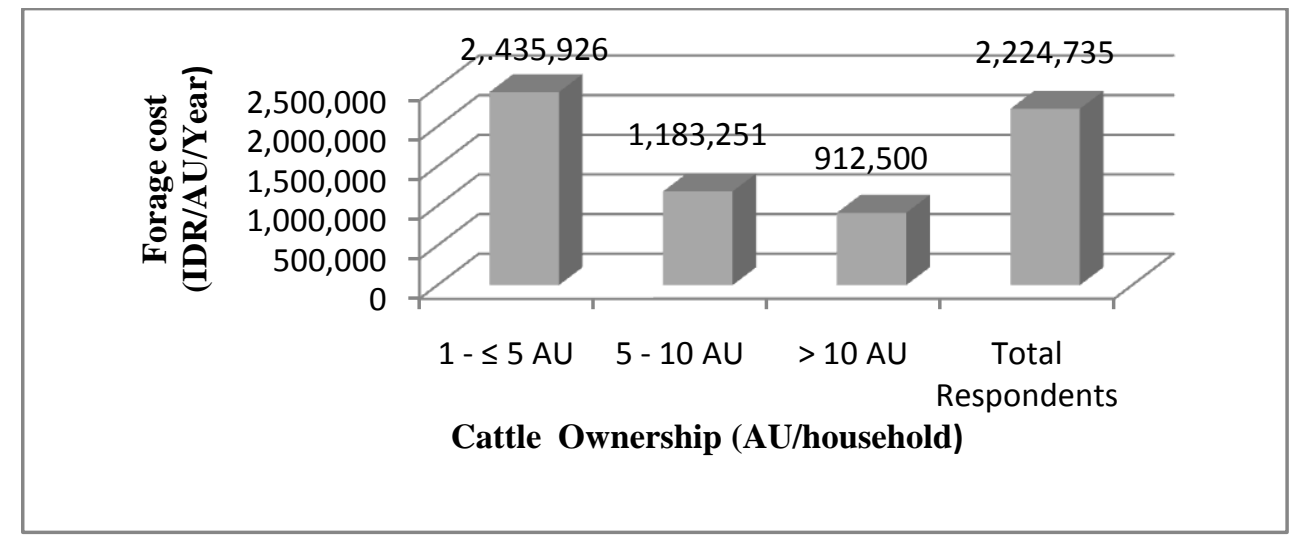

Figure 1. Forage cost per animal unit of cattle

Farmer feeds the livestocks 3 times during the day at different places that have a lot of forage supplies around of village because breeders used to tied their cattle in a cage at night. Total cost per animal unit of cattle was decreased as the increased of herd size.

\section{Factors influencing farmers' income from cattle farming}

The regression analysis from 100 farmers are presented in Table 3 . The results showed all of the dependent variables have affect to farmers income from cattle farming as much as $84.37 \%\left(\mathrm{R}^{2}=0.8437\right)$. the regression coefficient indicated the extent to which specific independent variable can increase or decrease income or economic incentive.

Table 3. Factors influencing farmers' income from cattle farming 
Household Income Investigation In Smallholder Cattle Farming At Minahasa Regency North

\begin{tabular}{lcr}
\hline \multicolumn{1}{c}{ Independent variables } & Coefficient & Probability \\
\hline Constant & $7,208,853$ & 0.4182 \\
Number of cattle & $2,435,536^{* * *}$ & 0.0047 \\
Family labor force & $125,377.4^{* *}$ & 0.0328 \\
Value added of cattle & $0.147^{*}$ & 0.0792 \\
Land size & $-0.895^{*}$ & 0.0617 \\
Education of head & -6.339 & 0.8133 \\
Inseminator cost & $78.09^{* *}$ & 0.0236 \\
Cost of natural mating & $29.72^{* *}$ & 0.0422 \\
\hline
\end{tabular}

$=$ Level significantly of $0.01(\mathrm{P}<0.01)$

$* * *$ level significantly of $0.05(\mathrm{P}<0.05)$

${ }^{*}=$ level significantly of $0.1(\mathrm{P}<0.1)$

Table 3 indicated that there were six factors having an affect on households' income from cattle farming and only variable of education of head was completely not significant. It was found in research area that most heads of family had high school education. The variables that can significantly increase income were number of cattle $(\mathrm{P}<0.01)$, family labor, inseminator cost, cost of natural mating $(\mathrm{P}<0.05)$ and value added of cattle $(\mathrm{P}<0.1)$ whereas land size would decrease farmers income from cattle business $(\mathrm{P}<0.1)$ since household workforce was mostly used on their bigger cultivated land area The study was in line with previous study $[18,19]$ that factors such as number of cattle, family labor and land size had significant impact for cattle farming income but inconsistence with another study [20,21] who reported that cost of insemination had not significant effect toward farmers' income from cattle business. Number of cattle determined farmers' income because the higher of cattle ownership, the farmer can sold more cattles, rent out cattle labors as well studs and obtain more income. Family labor effected farmers' income from cattle because all activities in order to kept good performance and productivity of cattle such as feeding, bathing, mating, dragging into stable and curing was carried out by family members. The better of performance and productivity will increased the price of cattle , thus would also increase revenue for farmer. Cattle produced by insemination was more expensive than natural mating. Nevertheless the availability of inseminator officer was limited so that breeder had to pay more cash to inseminate their cattle. The more the inseminator cost the more the cattle will be inseminated and thus farmer would obtain more income. Value added of cattle had significantly positive impact on farmers income since the farmer raises ongole - crossbreed type that are appropriate with the condition and necessity of society in research area. Value added of cattle in Village of Tumaratas relies on cattle variety, total of cattle ownership and cattle condition as well. In research area, the cattle selling price is dependable on the physical appearance of cattle since the cattle was used as labor assisting farmer's task, thus, if the breeder sells their cattle as beef then the price will be lower.

\section{Conclusion}

The income of haousehold per animal unit tended to increase with an increase in herd size. Cattle farming business had more than 50 percent contribution on household Income in all strata ownership. The lower the cattle owned the more the income from non farm activities obtain by farmers. Factors that significantly influenced farmers' income on dual purpose of cattle farming in Minahasa Regency were number of cattle, family labor force, value added of cattle, land size, inseminator cost and cost of natural mating

\section{References}

[1] O.M. Kocturk, A case study of increasing income of dairy cattle in rural areas in western part of Turkey, Journal of Animal and Veterinary Advances, 8(9),2009, 1685-1699.

[2] Pasuruan regency, East Java, Indonesia. Livestock Research for Rural Development, 25(10), 2013, paper 180,

[3] L.K. Mabe, M.A. Antwi,. and O.I. Oladele, Factors influencing farm income in livestock producing communities of Northwest Province, South Africa. Livestock Research for Rural Development 22 (8), 2010, paper 142,

[4] A.J. Franzluebbers, Integrated crop-livestock systems in the southeastern USA, Agronomy. Journal, 99, 2007,361-372.

[5] L.S. Kalangi, Y. Syaukat, S.U. Kuntjoro and A. Priyanti, The Characteristics of Cattle Farmer Households and the Income of Cattle Farming Businesses in East Java, Journal of Agriculture and Veterinary Science, 7(12), 2014, 29-34

[6] W.Roessali, Masyhuri, N. Nurtini, and D.H. Darwanto, Factor Influencing Farmer's Decision To Increase Beef Cattle Business Scale in Central Java Province. Journal of Indonesian Tropical Animal Agriculkture., 36(1), 2011, 27-35.

[7] E. Wantasen, B. Hartono, N. Hanani, V.V.J.Panelewen, Household economic behavior of traditional cattle farmers in utilizing artificial insemination technology: a case study in village of Kanonang III, Minahasa Regency of Indonesa, Journal of Agriculture. And Food Technology, 2(8), 2012,141-152.

[8] C.M. Mapiye, Chimonyo, V. Muchenje, D. Kennedy, C. Munyaradzi, Marufu, and J. G. Raats, Potential for value-addition of nguni cattle products in the communal areas of South Africa: a review. African Journal of Agricultural Research, 2(10), 2007, 488495.

[9] M.B.Salem, and H Khemiri, The impact of agricultural projects on beef's productivity, farmers' revenue and rural development in Tunisia. Livestock Research for Rural Development 20 (5), 2008, 88-96.

[10] P.K. Sarma., and J.U Ahmed, An economic study of small scale cattle fattening enterprise of rajibari district. Journal Bangladesh Agriculture, 9(1), 2011, :141-146. 
[11] [N.P.Sikhweni, and R. Hassan, Opportunities and challenges facing small-scale cattle farmers living adjacent to Kruger National Park, Limpopo Province. Journal. of Emerging Trends in Economics and. Management Science., 5(1), 2013, 38-43

[12] S.D. Anis, E. Wantasen, S..Dalie, D.A. Kaligis, and U. Paputungan, Beef cattle feasibility study of household farm in Bolmong Regency, North Sulawesi Province of Indonesia, International Journal of. Agricultural Scences. and Natural Resources., 2(2), 2015, 36-39

[13] H. D Utami, B. D Maharani and A.P. Seruni, The Role dairy farming in generating rural household income at east Java Indonesia, Journal of Applied Science and Agriculture, 9(11), 2014, 201-206.

[14] F. Bagamba, K. Burger, and A. Kuyvenhoven, Determinants of smallholder farmer labour allocation decisions in Uganda, paper presented in the EAAE seminar on Pro-poor development in low income countries: Food, agriculture, trade and environment, Montpellier, France. 2007, 286-294

[15] P.Knottnerus, Sample survey theory: Some pythagorean perspectives (New york : Springer Science Business Media , 2003

[16] D.N. Gujarati, Basic econometric. fourth edition (New York): Mc Graw Hill, 2003

[17] S.Purnomo, The simulation model of beef cattle household' incone development policy (Case study at Damsol District, Donggala Regency,) doctoral diss, Brawijaya University Malang, 2010

[18] E.A. Ouma, G. A., Obare, and S.J. Staal, Cattle as assets : assessment of non market benefits from cattle in smallholder Kenyan crop-livestock system, Proc. 25 ${ }^{\text {th }}$, International Conference of Agricultural Economists (IAAE), Durban, South Africa, 16-22 August, 2003, 328-334

[19] I.N. Maina, I.U. Leonhauser, and S. Bauer, Adoption of improved agricultural technologies among smallholder farm households in Nakuru District, Kenya, Journal of Agricultural Extension and Rural Development,. 4(8), 2012, 147-163

[20] H. Kaaya, B. Bashasha, and D. Mutetikka, Determinants of utilisation of artificial insemination (AI) services among Ugandan dairy farmers, Proc. African Crop Science Conference. Uganda, 2005.. 561-567

[21] K. Bart, A. C Mayer, C..A Gomez, E Muñoz, H.D Hess, and F Holmann, Economic evaluation of the current and alternative dual-purpose cattle systems for smallholder farms in the Central Peruvian highlands. Agricultural Systems 101 (3),2009,. 152-161 